Anna Doliwa-Klepacka

\title{
MOŻLIWOŚCI ODSTAZPIENIA OD REŻIMU WIZOWEGO PRZY PRZEKRACZANIU ZEWNĘTRZNEJ GRANICY UNII EUROPEJSKIEJ
}

\section{Uwagi wstępne}

Uwspólnotowienie polityki wizowej w Unii Europejskiej niejednokrotnie oznaczało w praktyce zaostrzenie reżimu prawnego w tym obszarze wobec obywateli państw sąsiadujących z państwami członkowskimi. Bardzo wyraźnym przykładem tego typu zjawiska było przyjęcie wspólnych regulacji wizowych przez państwa Europy Środkowo-Wschodniej, w tym Polskę, w związku z akcesją do Unii Europejskiej. W konsekwencji przywrócony został reżim wizowy wobec m.in. obywateli Rosji, Białorusi i Ukrainy. W odniesieniu do obywateli Rosji powstał dodatkowy problem w momencie włączenia Polski i Litwy do strefy Schengen. Nie rozwiązano bowiem problematycznej kwestii tranzytu obywateli Federacji Rosyjskiej (z i do Obwodu Kaliningradzkiego) przez terytorium państw członkowskich Unii Europejskiej.

Na przykładzie relacji z niebędącymi członkami Unii Europejskiej państwami ościennymi Polski można stwierdzić, że realizacja wspólnej polityki wizowej Unii wpływa na dwustronne kontakty. Dla wyeliminowania części problemów praktycznych Unia Europejska zawarła m.in. z Rosją (25 maja 2006 r.) i Ukrainą (18 czerwca 2007 r.) umowy o ułatwieniach w wydawaniu wiz. Nie są one jednak postrzegane jako rozwiązanie istniejących problemów - wciąż pojawia się postulat docelowej zmiany reżimu wizowego. Dla ułatwienia rozwoju wzajemnych kontaktów (zarówno społecznych, naukowych, gospodarczych, jak i kulturalnych) liberalizacja reżimu wizowego wobec obywateli wschodnich państw sąsiadujących Polski jest bardzo istotna. Nie zapominając o postulatach perspektywicznych, warto zwrócić uwagę na obecne możliwości odstapienia od reżimu wizowego przy przekraczaniu zewnętrznej granicy Unii Europejskiej. 
Możliwości odstapienia od reżimu wizowego przy przekraczaniu zewnętrznej granicy...

\section{Zakres dopuszczalnych zwolnień z obowiązku wizowego w Unii Europejskiej}

Kluczowym aktem prawnym Unii Europejskiej w zakresie wspólnej polityki wizowej jest rozporządzenia Rady (WE) nr 539/2001 z dnia 15 marca 2001 r. wymieniające państwa trzecie, których obywatele muszą posiadać wizy podczas przekraczania granic zewnętrznych oraz te, których obywatele są zwolnieni z tego wymogu (ze zm.). ${ }^{1} \mathrm{~W}$ art. 1 ust. 2 tegoż rozporządzenia zawarto katalog przypadków, objętych całkowitymi zwolnieniami z obowiązku wizowego przy przekraczaniu granic zewnętrznych państw członkowskich:

- podstawowe i najszersze wyłączenie dotyczy obywateli takich państw trzecich, które ujęte zostały w wykazie pozytywnym (tzw. biała lista), stanowiącym załącznik nr II do rozporządzenia, gdy ich całkowity pobyt na terytorium UE nie przekracza trzech miesięcy;

- drugi przypadek dotyczy obywateli państw trzecich, znajdujących się na liście w załączniku I do rozporządzenia 539/2001, którzy przekraczają granicę zewnętrzną w ramach małego ruchu granicznego; ${ }^{2}$

- trzeci - uczniów, którzy są obywatelami państwa trzeciego znajdującego się na liście w załączniku I, a zamieszkują na stałe w państwie członkowskim stosującym decyzję Rady 94/795/WSiSW z dnia 30 listopada 1994 r. w sprawie wspólnych działań przyjętych przez Radę na podstawie art. K. 3 ust. 2 lit. b) Traktatu o Unii Europejskiej w sprawie ułatwień podróży dla uczniów pochodzących z państw trzecich przebywających w państwach członkowskich $^{3}$ - w przypadku uczestniczenia w wycieczce szkolnej w grupie uczniów pod opieką nauczyciela danej szkoły;

Rozporządzenie to od momentu wejścia w życie było zmieniane 8 razy przez:

rozporządzenie Rady (WE) nr 2414/2001 z dnia 7 grudnia 2001 r. (Dz.U. L 327 z 12.12.2001, s. 23); rozporządzenie Rady (WE) nr 453/2003 z dnia 6 marca 2003 r. (Dz.U. L 69 z 13.3.2003, s. 10); rozporządzenie Rady (WE) nr 851/2005 z dnia 2 czerwca 2005 r. (Dz.U. L 141 z 4.6.2005, s. 3); rozporządzenie Rady (WE) nr 1791/2006 z dnia 20 listopada 2006 r. (Dz.U. L 363 z 20.12.2006, s. 1); rozporządzenie Rady (WE) nr 1932/2006 z dnia 21 grudnia 2006 r. (Dz.U. L 405 z 30.12.2006, s. 1), rozporządzenie Rady (WE) nr 1244/2009 z dnia 30 listopada 2009 (Dz.U. L 336 18.12.2009, s. 1), rozporządzenie Rady (UE) nr 1091/2010 z dnia 24 listopada 2010 r. (Dz.U. L 329 z 14.12.2010, s. 1) oraz rozporządzenie Rady (UE) nr 1211/2010 z dnia 15 grudnia 2010 r. (Dz.U. L 339 z 22.12.2010, s. 9). Wersja skonsolidowana z 11.01.2011 r. - http://eur-lex.europa.eu/LexUriServ/LexUriServ.do?uri=CONSLEG:20 01R0539:20110111:PL:PDF - data wejścia 01.08.2011 r.

2 Zgodnie z rozporządzeniem (WE) nr 1931/2006 Parlamentu Europejskiego i Rady z dnia 20 grudnia 2006 r. ustanawiającym przepisy dotyczące małego ruchu granicznego na zewnętrznych granicach lądowych państw członkowskich i zmieniajace konwencję z Schengen, Dz.U. L 405 z 30.12.2006, s. 1. 
- czwarty - osób posiadających status uchodźcy oraz wszystkich bezpaństwowców, ${ }^{4}$ którzy zamieszkują na stałe w państwie członkowskim i są posiadaczami dokumentu podróży wydanego przez to państwo członkowskie.

Państwom członkowskim pozostawiono jednocześnie możliwość wprowadzania odstępstw od przewidzianego w art. 1 ust. 2 zniesienia obowiązku wizowego w odniesieniu do osób, które w trakcie swego pobytu na terytorium danego państwa prowadzą działalność zarobkową.

Oprócz wspomnianych wyżej przypadków wyłączeń wskazanych wprost w rozporządzeniu 539/2001, przewidziano możliwość zastosowania dodatkowych odstępstw na podstawie decyzji poszczególnych państw członkowskich (ze skutkiem prawnym ograniczonym do terytorium danego państwa). Na mocy art. 4 ust. 1 ww. rozporządzenia państwo członkowskie może swobodnie stosować indywidualne odstępstwa od obowiązku wizowego przewidzianego w art. 1 ust. 1 lub od zwolnienia $\mathrm{z}$ obowiązku wizowego przewidzianego w art. 1 ust. 2 (tj. wprowadzić zwolnienia z obowiązku wizowego wobec niektórych kategorii obywateli państw trzecich znajdujących się w wykazie negatywnym lub nałożyć obowiązek wizowy na niektóre kategorie obywateli państw trzecich znajdujących się w wykazie pozytywnym). Takie działania państwo członkowskie może zastosować wobec następujących kategorii osób:

- posiadaczy paszportów dyplomatycznych, paszportów służbowych/urzędowych lub paszportów specjalnych, według jednej z procedur określonych w art. 1 ust. 1 i art. 2 ust. 1 rozporządzenia (WE) nr 789/2001 z dnia 24 kwietnia 2001 r. zastrzegającego dla Rady uprawnienia wykonawcze w odniesieniu do niektórych szczegółowych przepisów i procedur praktycznych rozpatrywania wniosków wizowych; ${ }^{5}$

- cywilnych załóg samolotów i statków;

- załóg i obsługi lotów w ramach misji awaryjnych lub ratunkowych oraz innych osób niosących pomoc w przypadku katastrofy lub wypadku;

- członków cywilnych załóg statków żeglujących po wodach międzynarodowych;

Zarówno objętych konwencją dotyczącą statusu bezpaństwowca z dnia 28 września 1954 r., jak i nieobjętych zakresem zastosowania tej konwencji.

5 Dz.U. L 116 z 26.4.2001, s. 2, polskie wydanie specjalne: Rozdział 19 Tom 04 P. 99 - 101 - zob. tekst http://eurlex.europa.eu/Notice.do?val=259281: $\mathrm{cs} \&$ lang=pl\&list=261461:cs, $259281: \mathrm{cs}, \&$ pos=2\&page=1\&nbl=2\&pgs=10\& hwords $=\&$ checktexte=checkbox\&visu=\#texte - data wejścia 09.08.2011 r. Rozporzaldzenie to zostało zmienione decyzją Rady 2004/927/WE (Dz.U. L 396 z 31.12.2004, s. 45), a następnie uchylone rozporządzeniem Rady (WE) nr 810/2009 ustanawiającym wspólnotowy kodeks wizowy (kodeks wizowy), Dz.U. L 243 z 15.9.2009, s. 1 $-\mathrm{z}$ dniem 04.04.2010 r. 
- posiadaczy listów żelaznych wystawionych przez niektóre międzynarodowe organizacje międzyrządowe swym urzędnikom.

We wskazanych wyżej przypadkach swobodnej praktyki państw niejednokrotnie mamy do czynienia z quasi-harmonizacją, ponieważ praktyka ta jest często identyczna. Np. zgodnie z obecnymi informacjami przekazanymi Komisji przez państwa członkowskie cywilne załogi samolotów są zwolnione z obowiązku wizowego we wszystkich państwach członkowskich. W odniesieniu do cywilnych załóg statków morskich zwolnienie z obowiązku wizowego w przypadku zejścia na ląd wprowadziło 25 państw członkowskich. Analogiczna ilość państw członkowskich zachowała obowiązek posiadania wizy w przypadkach tranzytu. Tylko jedno państwo członkowskie stosuje natomiast zwolnienie z obowiązku wizowego wobec załóg i obsługi lotów w ramach misji awaryjnych lub ratunkowych oraz wobec innych osób niosących pomoc w przypadku katastrofy lub wypadku. W odniesieniu do kategorii obejmującej członków cywilnych załóg statków żeglujących po śródlądowych wodach międzynarodowych (np. Ren, Dunaj) występuje różnorodna praktyka państw, jeśli chodzi o zwolnienie z obowiązku wizowego lub nałożenie takiego obowiązku w odniesieniu do wspomnianej kategorii osób. ${ }^{6}$

W art. 4 ust. 2 rozporządzenia 539/2001 przewidziano ponadto, że państwo członkowskie może także zwolnić z obowiązku wizowego:

- uczniów, którzy są obywatelami państwa trzeciego, znajdującego się na liście w załączniku I rozporządzenia, a zamieszkują na stałe w państwie trzecim znajdującym się na liście w załączniku II lub w Szwajcarii i Liechtensteinie - w przypadku uczestniczenia w wycieczce szkolnej w grupie uczniów pod opieką nauczyciela danej szkoły;

- osoby posiadające status uchodźcy i bezpaństwowców, jeśli państwo trzecie, w którym zamieszkują na stałe i które wydało im dokument podróży, jest jednym z państw trzecich wymienionych w załączniku II rozporządzenia;

- członków sił zbrojnych podróżujących w sprawach NATO lub Partnerstwa dla Pokoju, posiadających dowód tożsamości i rozkaz wyjazdu określone w umowie między państwami-stronami Umowy pomiędzy stronami Organizacji Paktu Północnoatlantyckiego dotyczącej statusu ich sił zbrojnych $\mathrm{z}$ dnia 19 czerwca $1951 \mathrm{r}$.

W maju 2011 r. Komisja Europejska przedstawiła wniosek legislacyjny dot. rozporządzenia Parlamentu Europejskiego i Rady zmieniającego rozporządzenie 
Rady (WE) nr 539/2001 wymieniające państwa trzecie, których obywatele muszą posiadać wizy podczas przekraczania granic zewnętrznych oraz te, których obywatele są zwolnieni z tego wymogu. ${ }^{7}$ Celem proponowanej zmiany jest m.in. poczynienie postępów w kierunku pełnej harmonizacji wspólnej polityki wizowej poprzez wprowadzenie nowych, bardziej zharmonizowanych przepisów dotyczących obowiązkuwizowego lub zwolnienia $\mathrm{z}$ obowiązku wizowego stosowanych względem różnychkategorii obywateli państw trzecich.

W projekcie tym Komisja proponuje m.in. wprowadzenie do art. 4 rozporządzenia 539/2001 przepisu umożliwiającego państwom członkowskim zwolnienie z obowiązku wizowego osób świadczących usługi - zwolnienie to mogłoby być stosowane w zakresie koniecznym do poszanowania zobowiązań międzynarodowych podjętych przez Wspólnotę przed wejściem w życie rozporządzenia (WE) nr 539/2001. Przykładem mogą być np. umowy międzynarodowe, zawierane przez Wspólnotę Europejską i jej państwa członkowskie z państwami trzecimi (takie jak układy o stowarzyszeniu), a dotyczące $\mathrm{m}$. in. przepływu osób i usług i mogące mieć tym samym wpływ na obowiązek wizowy nakładany na obywateli państw trzecich. Tego rodzaju umowy międzynarodowe mają pierwszeństwo w stosowaniu wobec przepisów prawa wtórnego, w tym również rozporządzenia (WE) nr 539/2001. ${ }^{8}$ Państwa członkowskie, których dotyczy derogacja (klauzula zawieszająca), zawarta we wspomnianych umowach międzynarodowych, powiadamiają o tym Komisję i pozostałe państwa członkowskie. ${ }^{9}$

Należy przypomnieć, że problem ten był przedmiotem postępowania przed Trybunałem Sprawiedliwości w sprawie C-228/06 MehmetSoysal i Ibrahim Savatli przeciwko Bundesrepublik Deutschland. ${ }^{10} \mathrm{~W}$ wyroku z dnia 9 lutego 2009 r. Trybunał odniósł się do postanowień protokołu dodatkowego do Układu ustanawiającego stowarzyszenie między Europejską Wspólnotą Gospodarczą a Turcją (Układ podpisany w dniu 12 września $1963 \mathrm{r}$. w Ankarze) - protokół ten został podpisany w dniu 23 listopada 1970 r. w Brukseli i zgodnie z jego art. 62 stanowi integralną część układu stowarzyszeniowego. W art. 41 ust. 1 tego protokołu ustanowiona została klauzula zawieszająca (standstill), która stanowi, że umawiające się strony nie będą wprowadzać żadnych nowych ograniczeń w swobodzie przedsiębiorczości

7 COM/2011/0290 końcowy - COD 2011/0138, http://eur-lex.europa.eu/LexUriServ/LexUriServ. do?uri=COM:2011:0290:FIN:PL:PDF - data wejścia 11.08.2011 r.

8 Jeśli tego rodzaju umowy międzynarodowe zawierają tzw. klauzulę zawieszająca, może z nich dla niektórych państw członkowskich wynikać obowiązek odstapienia od stosowania reguł wspólnej polityki wizowej zgodnie $z$ ich ustawodawstwem krajowym i przepisami obowiązującymi w dniu wejścia w życie w stosunku do nich klauzuli zawieszającej.

9 Obecnie jedynie układ stowarzyszeniowy z Turcją zawiera wspomnianą klauzulę zawieszająca.

10 Wniosek o wydanie orzeczenia w trybie prejudycjalnym złożony przez Oberverwaltungsgericht Berlin-Brandenburg - Niemcy, wyrok z dnia 19.02.2009r. - Zb.Orz. TS 2009 Strona I-01031, zob. http://eur-lex.europa.eu/Notice.do?val=488992:cs\&lang=pl\&list=494138:cs,488992:cs \&pos=2\&page=1\&nbl=2\&pgs=10\&hwords=Mehmet\% 20Soysal \&checktexte=checkbox\&visu=\#texte - data wejścia 19.08.2011 r. 
i w swobodzie świadczenia usług. ${ }^{11}$ Trybunał podkreślił, że zgodnie z utrwalonym orzecznictwem, przepis art. 41 ust. 1 wywołuje skutek bezpośredni - ustanawia bowiem w sposób jasny, precyzyjny i bezwarunkowy jednoznaczną klauzulę ,standstill', zawierającą nałożony na siebie przez umawiające się strony obowiązek, który pod względem prawnym sprowadza się do powstrzymania się od działań. ${ }^{12} \mathrm{~W}$ sentencji wyroku Trybunał orzekł, że artykuł 41 ust. 1 protokołu dodatkowego do Układu EWG - Turcja należy interpretować w ten sposób, że stoi on na przeszkodzie wprowadzeniu względem obywateli tureckich po dacie wejścia w życie tego protokołu wymogu posiadania wizy przy wjeździe na terytorium państwa członkowskiego w celu świadczenia w tym państwie usług na rachunek przedsiębiorstwa mającego siedzibę w Turcji, ponieważ w chwili wejścia w życie tego protokołu wiza nie była wymagana.

\section{Mały ruch graniczny jako przykład zwolnienia z obowiązku wizowego}

Jak wspomniano wcześniej, w katalogu obecnych zwolnień z obowiązku wizowego przy przekraczaniu zewnętrznej granicy państw członkowskich Unii Europejskiej ujęte zostały osoby przemieszczające się w ramach małego ruchu granicznego. ${ }^{13}$ Postulat zniesienia barier (w tym przypadku wizowych) we wzajemnych kontaktach był w regionach przygranicznych szczególnie istotny, ponieważ ich mieszkańcy tradycyjnie są silnie uzależnieni od rozwoju przygranicznego handlu czy usług. Z drugiej strony - na skutek m.in. przesunięć w przebiegu granic państwowych - nierzadkie są sytuacje, gdy członkowie rodzin czy nekropolie rodzinne usytuowane są na terytorium innego państwa. W regionach przygranicznych zarówno względy ekonomiczne, jak i społeczne czy kulturalne są zatem ważnym wskazaniem na rzecz zastosowania rozwiązań łagodzących, czy wręcz znoszących ogólny reżim wizowy. Ciekawym przykładem tego rodzaju jest instytucja małego ruchu granicznego.

„Lokalny ruch graniczny"14 od dawna postrzegany był jako istotny element związany z funkcjonowaniem zewnętrznych granic Unii Europejskiej. Niektóre

11 W stosunku do Republiki Federalnej Niemiec protokół dodatkowy wszedł w życie w dniu 1 stycznia 1973 r.

12 Zob. pkt 45 wyroku.

13 Na podstawie rozporządzenia Rady (WE) nr 1932/2006 z dnia 21 grudnia 2006 r. zmieniającego rozporządzenie (WE) nr 539/2001 wymieniające państwa trzecie, których obywatele muszą posiadać wizy podczas przekraczania granic zewnętrznych, oraz te, których obywatele są zwolnieni z tego wymogu (Dz.U. L 405 z 30.12.2006), http://eur-lex.europa.eu/Notice.do?val=442711:cs\&lang=pl\&list=442711:cs,443269:cs,\&pos=1\&page=1\&nbl=2\& pgs $=10 \&$ hwords $=\&$ checktexte=checkbox\&visu=\#texte, data wejścia 02.08.2006 r.

14 Tj. regularne i częste przekraczanie granicy przez osoby mieszkające w obszarze przygranicznym kraju sąsiadującego. Termin „lokalny ruch graniczny” był używany w omawianym obszarze w pierwszych dokumentach przyjmowanych na poziomie Unii. Na ten temat zob. np. B. Fieducik, Instytucje małego ruchu granicznego, (w:) M. Zdanowicz (red.), Polska w Schengen, Białystok 2009, s. 37 i nast. Na terminologię warto zwrócić uwagę 
z państw członkowskich zawarły z państwami sąsiadującymi umowy dwustronne regulujące to zagadnienie. ${ }^{15} \mathrm{~W}$ związku z wprowadzeniem wspólnych reguł polityki wizowej Komisja podnosiła konieczność ustanowienia również przepisów wspólnotowych, określających kryteria i warunki wprowadzenia ułatwień dla mieszkańców strefy przygranicznej przy przekraczaniu zewnętrznej granicy w ramach zasad małego ruchu granicznego. ${ }^{16}$ Podkreślano, że wspólne reguły w tym zakresie powinny zapewnić równowagę pomiędzy dwiema ważnymi kwestiami. $Z$ jednej strony chodzi bowiem o ułatwianie przekraczania granicy mieszkańcom strefy przygranicznej działającym w dobrej wierze i mającym uzasadnione powody do częstego przekraczania zewnętrznej granicy Unii Europejskiej. Z drugiej zaś - o potrzebę zapobiegania nielegalnej imigracji oraz potencjalnym zagrożeniom dla bezpieczeństwa, jakie stanowi działalność przestępcza. Ostatecznie w grudniu 2006 r. Parlament Europejski i Rada przyjęły rozporządzenie ustanawiające przepisy dotyczące małego ruchu granicznego na zewnętrznych granicach lądowych państw członkowskich i zmieniające postanowienia Konwencji z Schengen (rozporządzenie (WE) nr 1931/2006 $\mathrm{z}$ dnia 20 grudnia 2006 r. $)^{17}$

Wspomniane rozporządzenie przewiduje możliwość zastosowania szeregu wyjątków w porównaniu ze standardowymi wymogami odnośnie do warunków wjazdu na terytorium państwa członkowskiego oraz kontrolami na zewnętrznych granicach Unii Europejskiej, określonymi m.in. w kodeksie granicznym Schengen. Reżim małego ruchu granicznego jest jednak dość ściśle ograniczony terytorialnie - zezwolenie pozwala jego posiadaczowi na poruszanie się tylko w obszarze strefy przygranicznej państwa, które zezwolenie wydało.

Aby móc korzystać z zasad małego ruchu granicznego, mieszkańcy strefy przygranicznej muszą spełniać szereg warunków. Do najważniejszych zalicza się m.in. wymóg zamieszkiwania w strefie przygranicznej przez okres przynajmniej 1 roku, czy posiadanie ważnego dokumentu podróży. Ubiegający się o zezwolenie na przekraczanie granicy w ramach małego ruchu granicznego nie mogą być objęci wpisem w systemie informacji Schengen do celów odmowy wjazdu. Nie mogą być również uważani za osoby stanowiące zagrożenie dla porządku publicznego, bezpieczeństwa wewnętrznego, zdrowia publicznego lub stosunków międzynarodowych któregokolwiek z państw członkowskich.

w kontekście rozporządzenia nr 1931/2006 z dnia 20.12.2006 r. - w polskiej wersji urzędowej przyjęty jest termin „mały ruch graniczny”, w angielskiej np. nadal - „local border traffic”.

Komisja dokonała przeglądu takich umów - patrz „Rozwój acquis w zakresie lokalnego ruchu granicznego”, SEC(2002)947 z 9.9.2002 r.

16 Zob. komunikat Komisji „W kierunku zintegrowanego zarządzania zewnętrznymi granicami Państw Członkowskich Unii Europejskiej" COM (2002)233 z 7.5.2002 r.

17 Dz.U. L 405 z 30.12.2006, s. 1-18 (PL), http://eur-lex.europa.eu/LexUriServ/LexUriServ.do?uri=OJ: L:2006:405:0001:0018:PL:PDF. Szerzej nt. genezy wspólnych regulacji w tym obszarze - zob. M. Zdanowicz, A. Doliwa-Klepacka, Możliwości liberalizacji reżimu wizowego w ramach współpracy państw w Partnerstwie Wschodnim, (w:) Partnerstwo wschodnie. Wymiary realnej integracji, red. M. Zdanowicz, T. Dubowski, A. Piekutowska, Białystok 2010, s. 156-157. 
Posiadacze zezwoleń na przekraczanie granicy w ramach małego ruchu granicznego są zwolnieni z wymogu wizowego (jeśli taki wymóg istnieje). Nie muszą również spełniać warunku posiadania dostatecznych środków utrzymania (na czas zamierzonego pobytu i na powrót). Na przejściach granicznych nie można ponadto wymagać od nich przedstawiania dokumentów uzupełniających, potwierdzających cel ich pobytu.

Istotne ułatwienie dotyczy czasu pobytu. Osoby uprawnione w ramach zasad małego ruchu granicznego mogą przebywać na terytorium właściwego kraju sąsiadującego bez ograniczeń czasowych, jednak każdy nieprzerwany pobyt nie może przekraczać 90 dni. Stanowi to odstępstwo od standardowej zasady, określonej w kodeksie granicznym Schengen, według której pobyt krótkoterminowy jest ograniczony do maksymalnie 90 dni na przestrzeni 180 dni.

Poza tym należy też zwrócić uwagę na inne ułatwienia, w tym m.in.:

- zezwolenia na przekraczanie granicy w ramach małego ruchu granicznego mogą być wydawane nieodpłatnie;

- zezwolenia mogą być wydawane na okres ważności od 1 roku od 5 lat;

- na potrzeby małego ruchu granicznego mogą być tworzone specjalne przejścia graniczne;

- na zwykłych przejściach granicznych mogą być wydzielane specjalne pasy ruchu dla mieszkańców strefy przygranicznej;

- osoby posiadające zezwolenie na przekraczanie granicy w ramach małego ruchu granicznego są zwolnione z wymogu uzyskania stempla w paszporcie przy przekraczaniu granicy.

Kompetencja Unii w obszarze określania zasad przekraczania granic ma charakter wyłączny, jednak w art. 13 rozporządzenia 1931/2006 ustanawiającego przepisy dotyczące małego ruchu granicznego na zewnętrznych granicach lądowych państw członkowskich upoważnia się państwa członkowskie do utrzymywania lub zawierania umów dwustronnych z sąsiadującymi państwami trzecimi w celu wdrożenia zasad małego ruchu granicznego. Warunkiem jest oczywiście, że umowy takie są zgodne z przepisami rozporządzenia 1931/2006, co ma być kontrolowane m.in. poprzez obowiązkowe konsultacje państw członkowskich z Komisją przed każdokrotnym zawarciem lub zmianą stosownej umowy dwustronnej.

Dotychczas Komisja przedłożyła Parlamentowi Europejskiemu i Radzie dwa sprawozdania w sprawie wdrożenia i funkcjonowania zasad małego ruchu granicz- 
nego. Pierwsze zostało przyjęte 24 lipca 2009 r., ${ }^{18}$ drugie -9 lutego 2011 r. ${ }^{19}$ Jak wynika z danych przedstawionych przez Komisję, do czasu przedstawienia drugiego sprawozdania weszły w życie cztery umowy dotyczące małego ruchu granicznego, oparte o postanowienia rozporządzenia 1931/2006: pomiędzy Węgrami i Ukrainą (w styczniu 2008 r.), pomiędzy Słowacją i Ukrainą (we wrześniu 2008 r.), pomiędzy Polską i Ukrainą (w lipcu $2009 \mathrm{r}^{20}$ ) oraz pomiędzy Rumunią i Mołdawią (w październiku 2010 r.). W najbliższym czasie powinny ponadto wejść w życie umowy pomiędzy: Polską i Białorusią (podpisana w lutym 2010 r.), Łotwą i Białorusią (podpisana w sierpniu 2010 r.), Litwą i Białorusią (podpisana w październiku 2010 r.) oraz Norwegią i Rosją (podpisana w listopadzie 2010 r.).

\section{Mały ruch graniczny w praktyce}

Jak wynika z informacji zebranych przez Komisję, w praktyce państwa członkowskie w różnym stopniu korzystają z udogodnień dopuszczonych przepisami rozporząadzenia 1931/2006. ${ }^{21}$ W żadnej z przedstawionych Komisji do konsultacji umów dwustronnych nie wykorzystano wszystkich dostępnych ułatwień.

Większość krajów członkowskich stosuje rozwiązania bardziej restrykcyjne od wymogów określonych we wspomnianym rozporządzeniu. Np. w kwestii długości dopuszczalnego pobytu posiadaczy zezwolenia w ramach małego ruchu granicznego większość państw członkowskich zastosowała dodatkowe ograniczenie, tj. 90 dni w przeciagu 180 dni. Kolejny ważny w praktyce wymóg dotyczy minimalnego okresu zamieszkania w strefie przygranicznej jako warunku koniecznego dla skorzystania z rozwiązań małego ruchu granicznego. We wszystkich przedłożonych Komisji umowach okres ten przekracza jeden rok, wymagany w rozporządzeniu 1931/2006.22 Jak już zaznaczono, przepisy wspomnianego rozporząadzenia dają możliwość wydawania zezwoleń na przekraczanie granicy w ramach małego ruchu granicznego nieodpłatnie. W praktyce jednak jedynie jedna umowa przewidywała

\footnotetext{
18 COM 2009 (383), http://eur-lex.europa.eu/Notice.do?val=498654\%3Acs\&lang=pl\&list=498654\%3Acs\%2C\&pos $=1 \&$ page $=1 \& \mathrm{nbl}=1 \& \mathrm{pgs}=10 \& \mathrm{hwords}=\&$ checktexte=checkbox\&visu - data wejścia 13.08.2011 r.

19 COM 2011 (47), Drugie sprawozdanie z wdrażania i funkcjonowania przepisów dotyczących małego ruchu granicznego wprowadzonych rozporządzeniem nr 1931/2006, http://eur-lex.europa.eu/LexUriServ/LexUriServ. do?uri=COM:2011:0047:FIN:PL:PDF , data wejścia 7.10.2011. 20 Umowa między Rządem Rzeczypospolitej Polskiej a Gabinetem Ministrów Ukrainy o zasadach małego ruchu
granicznego, podpisana w Kijowie dnia 28 marca 2008 roku oraz Protokół, podpisany w Warszawie dnia 22 grudnia 2008 roku, między Rządem Rzeczypospolitej Polskiej a Gabinetem Ministrów Ukrainy o zmianie Umowy między Rządem Rzeczypospolitej Polskiej a Gabinetem Ministrów Ukrainy o zasadach małego ruchu granicznego, podpisanej w Kijowie dnia 28 marca - Dz.U. z 2008 r. Nr 103, poz 858. Zob. pierwsze sprawozdanie Komisji..., op. cit., s. 7-8. W kilku umowach okres ten wynosi aż 3 lata.
} 
takie rozwiązanie. W pozostałych opłaty za wydanie zezwolenia określano na poziomie od 20 do 35 euro. ${ }^{23}$

Jedną z kluczowych kwestii w omawianych rozwiązaniach jest samo zdefiniowanie „strefy przygranicznej”. Właściwe ujęcie strefy przygranicznej było jednym z najtrudniejszych punktów dyskusji dotyczącej projektu rozporządzenia w sprawie małego ruchu granicznego w 2006 r. W art. 3 ust. 2 rozporządzenia 1931/2006 przyjęto, iż jest to „strefa, która nie sięga dalej niż 30 kilometrów od granicy.Jednostki podziału administracyjnego, które mają być uznane za strefę przygraniczną, sąokreślane przez zainteresowane państwa w umowach dwustronnych, o których mowa wart. 13. Jeżeli część którejkolwiek takiej jednostki jest położona między 30 a 50 kilometrem od linii granicy, uznaje się ją mimo to za część strefy przygranicznej."

Jak wynika ze sprawozdań Komisji, w niektórych przedłożonych do zaopiniowania wynegocjowanych projektach umów (np. Węgry - Ukraina, Polska - Ukraina, Łotwa - Federacja Rosyjska, Słowacja - Ukraina, Polska - Białoruś, Bułgaria - Serbia, Bułgaria - była Jugosłowiańska Republika Macedonii) strefa przygraniczna definiowana jest niezgodnie z rozporządzeniem 1931/2006. Jako „strefę przygraniczną" określano w nich bowiem efektywnie całą strefę sięgającą $50 \mathrm{~km}$ od granicy (a nie, zgodnie z rozwiązaniem, przyjętymw rozporządzeniu 1931/2006, strefę sięgającą nie dalej niż $30 \mathrm{~km}$ ). ${ }^{24} \mathrm{Komisja} \mathrm{nie} \mathrm{popierała} \mathrm{takiego} \mathrm{stanowiska.}{ }^{25} \mathrm{~W}$ jej ocenie z całościowej interpretacji art. 3 ust. 2 jasno wynika, że intencją prawodawcy było w zasadzie ograniczenie strefy przygranicznej do obszaru $30 \mathrm{~km}$. Komisja zaznaczyła, iż celem odstępstwa umożliwionego przez ostatnie zdanie wspomnianego artykułu (dotyczącego części jednostek administracyjnych leżących między 30 a $50 \mathrm{~km}$ ) jest zapobieżenie sytuacji, w której część jednostki administracyjnej leży częściowo w obrębie tej strefy przygranicznej, a częściowo poza nią.W związ$\mathrm{ku} z$ tym miejscowe rozszerzenia strefy przygranicznej dozwolone są w przypadkach, gdy dana jednostka administracyjna rozciaga się poza 30-kilometrową linię (częściowo leży w obrębie 30-kilometrowej strefy, a częściowo w strefie między 30 a $50 \mathrm{~km}$ od granicy).

W odpowiedzi na argumenty państw członkowskich dotyczące rozszerzenia zakresu terytorialnego „strefy przygranicznej” Komisja podkreślała, że w odniesieniu do niektórych krajów trzecich, np. Federacji Rosyjskiej i Ukrainy, istnieje inny in-

23 Porównywalnie do opłat wizowych dla obywateli państw, z którymi UE zawarła umowy o ułatwieniach wizowych (35 EUR).

24 Zob. pierwsze sprawozdanie Komisji... op. cit., s. 9 i nast. Na temat specyfiki, zasięgu terytorialnego i liczby ludności strefy przygranicznej w Polsce - zob. M. Zdanowicz, A. Doliwa-Klepacka, Możliwości liberalizacji reżimu wizowego w ramach współpracy państw w Partnerstwie Wschodnim, (w:) Partnerstwo wschodnie. Wymiary realnej integracji,_red. M.Zdanowicz, T. Dubowski, A. Piekutowska, Białystok 2010, s. 161-163. de 30 mais à moins de 50 kilomètres de la lignefrontalièreestnéanmoinsconsidéréecommeappartenant à la zonefrontalière") jasno wynika, że jedynie część jednostki administracyjnej sięgająca $50 \mathrm{~km}$ od granicy może być uważana za część strefy przygranicznej. 
strument, który powinien być wykorzystywany w odniesieniu do osób mających powody do częstego przekraczania granicy, a zamieszkujących poza obszarem strefy przygranicznej - umowa o ułatwieniach wizowych. ${ }^{26} \mathrm{Umowy}$ tego rodzaju pozwalają na nieodpłatne wydawanie pewnym kategoriom osób wiz wielokrotnego wjazdu o ważności do 5 lat.

Drugie sprawozdanie zostało przygotowane na podstawie odpowiedzi przekazanych przez osiemnaście państw członkowskich (Holandia, Włochy, Czechy, Hiszpania, Cypr i Bułgaria nie udzieliły odpowiedzi). W oparciu o uzyskane dane Komisja stwierdziła, że obecna definicja strefy przygranicznej (określona jako strefa 30 km, która może wyjątkowo zostać powiększona do $50 \mathrm{~km}$ ) jest odpowiednim kompromisem. Zwrócono jednak uwagę na szczególny problem Obwodu Kaliningradzkiego.

W konsekwencji rozszerzenia Unii w 2004 r. Obwód Kaliningradzki Federacji Rosyjskiej stał się jedyną enklawą na terytorium UE. Liczba ludności w tym okregu wynosi niemal milion, z czego 430000 osób zamieszkuje w stolicy, Kaliningradzie. Polska niejednokrotnie (nie tylko jednostronnie, lecz również wspólnie z Rosją czy Niemcami) wzywała do wprowadzenia zmian w rozporządzeniu w sprawie lokalnego ruchu granicznego, ,dostosowanych do szczególnej sytuacji obwodu kaliningradzkiego". W konsekwencji Komisja przedłożyła wniosek legislacyjny w sprawie zmiany rozporządzenia Parlamentu Europejskiego i Rady (WE) nr 1931/2006 w odniesieniu do włączenia obwodu kaliningradzkiego i niektórych powiatów polskich do obszaru uznawanego za strefę przygraniczna.. ${ }^{27}$

W uzasadnieniu wniosku w sprawie zmiany rozporządzenia 1931/2009 Komisja podnosiła, że przyczyni się on do rozwoju strategicznego partnerstwa między UE a Federacją Rosyjska, zgodnie z priorytetowymi celami określonymi w planie działania dotyczącym wspólnej przestrzeni wolności, bezpieczeństwa i sprawiedliwości w zakresie współpracy transgranicznej. W Unii Europejskiej nie spotyka się obszarów o podobnej sytuacji geograficznej jak Obwód Kaliningradzki - stosunkowo niewielki obszar, otoczony ze wszystkich stron państwami członkowskimi UE. Komisja uznała, że w drodze wyjątku cały obwód powinien zostać włączony do strefy przygranicznej - m.in. aby zapobiec izolacji Kaliningradu od jego bezpośrednich sąsiadów i ułatwić mieszkańcom obwodu podróżowanie. Komisja uznała, że o ile obowiązująca od 2007 r. umowa o ułatwieniach wizowych między UE a Federacją Rosyjską jest już istotnym krokiem na rzecz zwiększenia możliwości swobod-

Umowa między Wspólnotą Europejską a Federacją Rosyjską o ułatwieniach w wydawaniu wiz obywatelom Unii Europejskiej i Federacji Rosyjskiej z 25 maja 2006 r. - Dz.U. UE z 2007 r. L 129, s. 27; umowa między Wspólnotą Europejską a Ukrainą o ułatwieniach w wydawaniu wiz z 18 czerwca 2007 r. - Dz.U. UE z 2007 r. L 332, s. 66 . Notice.do?val=578214: $\mathrm{cs} \&$ lang $=$ pl\&list $=578214: \mathrm{cs}, \&$ pos $=1 \&$ page $=1 \& \mathrm{nbl}=1 \& \mathrm{pgs}=10 \&$ hwords $=\&$ checktexte $=$ che ckbox\&visu=\#texte, data wejścia - 05.10.2011 r. 
nego poruszania się, to przepisy dotyczące małego ruchu granicznego zapewniają dodatkowe ułatwienia w szczególności w przypadku regularnego, a nawet codziennego podróżowania na obszarze lokalnym. Z ułatwień mogliby ponadto korzystać wszyscy mieszkańcy obszaru kaliningradzkiego, zaś niektóre ułatwienia w ramach umowy o ułatwieniach wizowych między UE a Federacją Rosyjską przeznaczone są tylko dla wybranych kategorii osób. Komisja uznała, że dla zapewnienia rzeczywistych skutków rozporządzenia w tym regionie po polskiej stronie powinna zostać określona analogiczna strefa przygraniczna, co pozwoli ułatwić i zintensyfikować wymianę gospodarczą i kulturalną między obwodem kaliningradzkim a głównymi ośrodkami północnej Polski.

Dla zobrazowania stopnia wykorzystywania w praktyce instrumentu małego ruchu granicznego warto zwrócić uwagę na dane zebrane przez Komisję na potrzeby drugiego z przedłożonych sprawozdań w oparciu o informacje, przekazane przez państwa członkowskie. Statystyka odnośnie do korzystania przez mieszkańców stref przygranicznych z instrumentu małego ruchu granicznego w państwach, które zawarły stosowne umowy na bazie rozporządzenia 1931/2006, nie jest w pełni porównywalna, ponieważ okresy ujęte w zestawieniu Komisji są różne ze względu na odmienne terminy wejścia w życie umów.

Tabela 1. Liczba wydanych zezwoleń MRG

\begin{tabular}{|c|c|c|c|c|}
\hline Kraj & Liczba zezwoleń & Okres & $\begin{array}{c}\text { Całkowita liczba } \\
\text { uprawnionej ludności }\end{array}$ & $\begin{array}{c}\text { Liczba wydanych zezwo- } \\
\text { leń w stosunku do liczby } \\
\text { uprawnionej ludności }\end{array}$ \\
\hline Węgry & 58055 & $1 / 2008-5 / 2010$ & $400000-450000$ & około $13 \%$ \\
\hline Polska & 31652 & $7 / 2009-3 / 2010$ & $1,2 \mathrm{mln}$ & około $2,7 \%$ \\
\hline Słowacja & 1106 & $9 / 2008-6 / 2010$ & 415000 & około $0,3 \%$ \\
\hline Rumunia & 20.308 & $10 / 2010-12 / 2010$ & $1,2 \mathrm{mln}$ & około $2 \%$ \\
\hline
\end{tabular}

Źródlo: COM 2011 (47), Drugie sprawozdanie z wdrożenia i funkcjonowania przepisów dotyczqcych małego ruchu granicznego wprowadzonych rozporzadzeniem nr 1931/2006, s. 4.

Jak widać, zezwolenia w ramach małego ruchu granicznego cieszą się dużym zainteresowaniem wśród ludności zamieszkującej strefę przygraniczną na granicy ukraińsko-węgierskiej. Ma to swoje uzasadnienie - większość zamieszkałej tam ludności należy do węgierskiej mniejszości narodowej i utrzymuje silne więzy z krajem.

Komisja wskazała też statystyki dotyczące odrzuconych wniosków o wydanie zezwoleń. W okresie od grudnia 2007 r. do maja 2010 r. Węgry odrzuciły 838 wnio- 
sków, wyłącznie na podstawie wpisów do SIS oraz zakazów wjazdu do kraju i przebywania na jego terenie. Polska odrzuciła 272 wnioski w okresie od lipca 2009 r. do marca 2010 r., głównie w oparciu o wpisy do SIS, lecz również dlatego, że wnioskodawcy posiadali nadal ważne zezwolenia. Słowacja odrzuciła 169 wniosków w okresie od września 2008 r. do czerwca 2010 r., głównie dlatego, że wnioskodawcy nie przedstawili odpowiednio uzasadnionych przyczyn ekonomicznych częstego przekraczania granicy, co jest wymagane w umowie. Rumunia odrzuciła 972 wnioski od października do grudnia 2010 r., głównie dlatego, że wnioskodawcy nie przedstawili odpowiednio uzasadnionych przyczyn ekonomicznych częstego przekraczania granicy lub też uznano, że w ich przypadku występuje ryzyko nielegalnej imigracji. Odsetek odrzuconych wniosków waha się zatem od 13\% (SK), poprzez $4,7 \%$ (RO), $1,4 \%$ (HU) do $0,85 \%$ (PL) ${ }^{28}$

Ponadto z informacji zebranych przez Komisję wynika, że posiadacze zezwoleń w ramach małego ruchu granicznego przekraczają poszczególne granice regularnie, a jednorazowo pozostają na terytorium drugiego kraju zaledwie kilka godzin bądź jeden lub dwa dni. Przepisy dotyczące małego ruchu granicznego, tam gdzie stosowane, pozwalają realizować zakładany cel umożliwienia wymiany i współpracy transgranicznej i rzeczywiście stanowią ułatwienie dla ludności zamieszkującej w strefach przygranicznych.

Ciekawą kwestią są też oczywiście przypadki wykrytych przez państwa nadużyć i cofnięcia zezwoleń na przekraczania granicy. W okresie od stycznia do kwietnia 2010 r. Węgry ukarały grzywną 16 obywateli Ukrainy za przekroczenie maksymalnego okresu pobytu oraz odmówily wydania zezwolenia w 1231 przypadkach (zainteresowane osoby przebywały na terytorium Wegier przynajmniej przez trzy miesiące w ciagu sześciomiesięcznego okresu). W 2009 r. cofnięto dwa zezwolenia, a w ciągu pierwszych pięciu miesięcy 2010 r. cztery zezwolenia. Ponadto 18 zezwoleń uznano za nieważne, ponieważ już po ich wydaniu ich posiadaczom zakazano wjazdu na teren Węgier i przebywania na terytorium tego kraju.

Polska wykryła 15 przypadków nadużyć w okresie od lipca 2009 r. do kwietnia $2010 \mathrm{r}$. W dziewięciu przypadkach osoby przebywały poza strefą MRG, w pięciu osoby pozostały na terytorium Polski po wygaśnięciu terminu dozwolonego pobytu, a w jednym - osoba była zaangażowana w nielegalną działalność gospodarczą na terenie Polski. Te przypadki nadużyć skutkowały decyzjami o nakazie opuszczenia Polski i cofnięciu zezwoleń MRG. W okresie od lipca 2009 r. do marca 2010 r. podjęto 39 decyzji o cofnięciu zezwolenia MRG, co stanowi 1\% wszystkich wydanych w tym okresie zezwoleń. 
Możliwości odstapienia od reżimu wizowego przy przekraczaniu zewnętrznej granicy...

Rumunia wykryła 27 przypadków nadużyć w okresie od października do grudnia 2010 r. Cofnięto 22 zezwolenia i wydano pięć decyzji o powrocie.

Słowacja wykryła jeden przypadek nadużycia w okresie od września 2008 r. do czerwca 2010 r. - osobę, która się go dopuściła, wydalono z kraju. W tym samym okresie cofnięto 11 zezwoleń. Ponadto Słowacja poinformowała, że obywatele Ukrainy posiadali zezwolenia w ramach małego ruchu granicznego, wydawane przez różne państwa członkowskie, które to zezwolenia wykorzystywano do przekraczania określonych granic wewnętrznych (HU-SK, PL-SK). Słowacja podjęła środki mające na celu ukaranie tego typu zachowań. W nawiązaniu do tej kwestii Komisja stanęła na stanowisku, że przekraczanie granic wewnętrznych nie narusza przepisów dotyczących małego ruchu granicznego, o ile dane osoby pozostają w ramach odnośnych stref przygranicznych.

Na podstawie przedstawionych powyżej danych Komisja stwierdziła stosunkowo niską liczbę nadużyć, związanych z realizacją w praktyce postanowień umów o małym ruchu granicznym. W szczególności nie ma dowodów na to, że beneficjenci MRG mieliby systematycznie podróżować do innych państw członkowskich z naruszeniem obowiązujących przepisów. ${ }^{29}$

\section{Uwagi końcowe}

Obecne regulacje prawne Unii Europejskiej w obszarze polityki wizowej zawierają katalog możliwości zwolnienia z obowiązku wizowego albo wprost z mocy prawa, albo na podstawie zastosowania przez państwa członkowskie indywidualnych odstępstw. Obecny poziom wspólnych regulacji wciąż nie jest optymalny, dlatego Komisja przedstawiła w maju 2011 r. projekt kolejnego rozporządzenia wprowadzającego rozwiązania służące dalszej harmonizacji.

Przepisy dotyczące małego ruchu granicznego moga w istotnym stopniu ułatwić życie ludności zamieszkującej w pobliżu zewnętrznych granic lądowych państw członkowskich Unii Europejskiej, a stopień wykorzystania dopuszczalnych ułatwień zależy w znacznym stopniu od państw zawierających stosowne umowy dwustronne. Wbrew niektórym opiniom instrument małego ruchu granicznego nie wpływa szczególnie na działalność przemytnicza, a przypadki nadużywania zasad małego ruchu granicznego są rzadkie. Mimo niewykorzystywania w pełni przez państwa uprawnione wszystkich dopuszczalnych ułatwień, jest ważnym instrumentem wpływającym na ruch osobowy w regionach przygranicznych, przynajmniej częściowo rekompensującym zaostrzenie reżimu wizowego wobec obywateli wschodnich państw ościennych Unii Europejskiej. 


\section{ВОЗМОЖНОСТИ ОТСТУПЛЕНИЯ ОТ ВИЗОВОГО РЕЖИМА ПРИ ПЕРЕСЕЧЕНИИ ВНЕШНЕЙ ГРАНИЦЫ ЕВРОПЕЙСКОГО СОЮЗА}

В статье анализируется правовое регулирование Евросоюза в области визовой политики с точки зрения возможностей отступления от визового режима при пересечении внешней границы Евросоюза. Оно предполагает ряд возможностей освобождения от визовой обязанности либо в силу закона, либо на основании применения государствами-членами ЕС индивидуальных отступлений. По мнению Европейской Комиссии, существующий уровень совместного регулирования все еще не является оптимальным, поэтому ею в мае 2011 г. был представлен проект очередного распоряжения, предполагающего дальшейшую гармонизацию в данной сфере.

В статье проводится тщательный анализ положений, касающихся малого приграничного движения, например о полном освобождении от визовой обязанности при пересечении внешней границы государств-членов ЕС. Этот институт может существенно облегчить жизнь населения, проживающего вблизи внешних сухопутных границ Евросоюза, но все-таки степень использования допустимых отступлений от общего режима в значительной степени зависит от государств, заключающих соответствующие двусторонние договоры. Вопреки некоторым мнениям, инструмент малого приграничного движения существенно не влияет на рост контрабанды, а случаи злоупотребления его правилами немногочисленны 


\section{POSSIBILITIES FOR WAIVING THE VISA REQUIREMENT WHEN CROSSING THE EXTERNAL BORDERS OF THE EUROPEAN UNION}

This article explores the regulations of the European Union in the area of visa policy from the point of view of the possibility of waiving the visa requirement when crossing the external borders of the Member States of the European Union. The regulations provide a catalogue of possibilities for providing exemption from the visa obligation or ex lege, or on the basis of individual derogations applied by the Member States. The Commission considers that the current level of common regulations is still not optimal, and so in May 2011 it presented a draft of the forthcoming regulations introducing arrangements for further harmonization.

The article provides a closer analysis of the rules on local border traffic as an example of those instances that may be completely exempt from the visa requirement when crossing the external borders of the member states. This can substantially ease the life of the population living in the vicinity of the external land borders of the Member States of the European Union, however, the use of maximum accessibility depends to a large extent on the states that conclude relevant bilateral agreements. Contrary to some of the feedback, the instrument regarding small border traffic does not particularly affect the activities of smugglers, and cases of abuse of the rules on small border traffic are rare.

Key words:

Border, small border traffic, the European Union, visa policy, external border of the EU 